\title{
Optimalisasi Strategi Pemasaran BUMDes melalui E-Commerce di Era Pandemi Covid-19 (Studi Kasus BUMDes Madu Sejahtera Desa Segoromadu)
}

\author{
Optimization of BUMDes Marketing Strategy through E-Commerce in Covid-19 Pandemic Era \\ (Case Study of BUMDes for Prosperous Honey in Segoromadu Village)
}

Feby Septiansah Yudiarno ${ }^{1}$, Imamatur Rofi' ${ }^{2}{ }^{2}$, Risma Dwi Cahyani ${ }^{3}$, Nur Hayati ${ }^{4 *}$

1,2,3,4 Universitas Trunojoyo Madura; Jl Raya Telang, Kamal Bangkalan Kode Pos 69162;
* Correspondence: yatikmei77@gmail.com;

\section{Citation:}

Yudiarno , F.S., Rofi'a, I., Cahyani ,

R.D., Hayati, N. Optimalisasi

Strategi Pemasaran BUMDes melalui

E-Commerce di Era Pandemi Covid-

19 (Studi Kasus BUMDes Madu Se-

jahtera Desa Segoromadu). Buletin

Pemberdayaan Masyarakat dan Desa.

2021, 1(1), 1-12.

https://doi.org/10.21107/bpmd.v1i1. 11976

Received: July 2021

Accepted: August 2021

Published: September

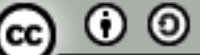

Copyright: () 2021 by the authors. Submitted for possible open access publication under the terms and conditions of the Creative Commons Attribution (CC BY SA) license (https://creativecommons.org/license s/by-sa/4.0/).

\begin{abstract}
Pandemi Covid-19 mampu mengubah aspek kehidupan manusia dari segi bisnis, termasuk usaha desa yaitu BUMDes. BUMDes Madu Sejahtera yang menawarkan berbagai produk dan layanan. Contoh produk yaitu bantal sofa, bantal leher, bantal tidur, dan guling. Untuk layanan jasa yaitu ada pembayaran listrik, pembayaran air, BPJS, maupun LPG. Namun, di tengah pandemi Covid-19 ini, BUMDes Madu Sejahtera mengalami hambatan terkait strategi pemasaran yang hanya melalui cara tradisional, yaitu mulut ke mulut. Berdasarkan kesempatan kali ini, penulis memiliki solusi untuk mengatasi hambatan tersebut dengan membuat e-commerce meliputi website dan media sosial guna membantu strategi pemasaran BUMDes di masa pandemi. Metode penelitian ini menggunakan peelitian deskriptif kualitatif. Teknik pengumpulan data adalah melalui berbagai kegiatan seperti wawancara, observasi, dan dokumentasi dengan ibu-ibu PKK selaku pengelola BUMDes. Hasil dari penelitian ini menunjukkan bahwa dengan adanya strategi pemasaran berbasis e-commerce mampu memperluas target pasar di luar masyarakat Desa Segoromadu serta meningkatkan nilai jual.
\end{abstract}

Keywords: Strategi Pemasaran, BUMDes, E-Commerce

\section{PENDAHULUAN}

Pengertian Badan Usaha Milik Desa atau biasa disingkat BUMDes merupakan badan usaha desa yang dikelola oleh masyarakat dan pemerintahan desa. Tujuan dari didirikannya usaha desa tersebut adalah agar perekonomian desa semakin kuat serta kehidupan masyarakat menjadi sejahtera berdasarkan kebutuhan dan potensi yang ada di lingkungan desa itu sendiri. Berdasarkan hal tersebut, sejalan dengan Undang-Undang No. 6 Tahun 2014 dan Peraturan Pemerintah No. 47 Tahun 2015 tentang Desa, Badan Usaha Milik Desa atau BUMDes merupakan usaha desa berbentuk badan usaha dengan sumber modalnya berasal dari alokasi dana desa yang dibedakan sebagai pengelolaan asset, pelayanan jasa, dan usaha lainnya demi kesejahteraan dan kontribusi masyarakat itu sendiri serta untuk memperkuat perekonomian desa.

Keberadaan BUMDes menjadi pertimbangan bagi pemerintahan desa untuk menyalurkan antusias dan partisipasi masyarakat sebagai upaya dalam pengembangan potensi desa kemudian dikelola dengan memanfaatkan sumber daya desa sehingga menciptakan nilai jual, dan mengoptimalkan sumber daya manusia dalam pengelolaannya. Menurut Saragih (2004), terdapat 5 tujuan pembentukan BUMDes, yaitu (a) dengan adanya usaha desa, keuangan desa dapat 
semakin meningkat; (b) untuk mengurangi angka pengangguran di desa, karena usaha desa mampu mengembangkan usaha masyarakat; (c) mendorong tumbuhnya jiwa untuk berwirausaha bagi masyarakat sekitar; (d) penyedia jaminan sosial; dan (e) layanan jasa.

BUMDes juga dinilai sebagai penggerak ekonomi. Fungsi BUMDes yaitu sebagai lembaga sosial dan komersial. Fungsi yang pertama yaitu sebagai lembaga sosial, artinya berpihak kepada kepentingan dan kesejahteraan masyarakat melalui kontribusinya sebagai pengelola atau penyedia pelayanan sosial. Sedangkan fungsi yang kedua yaitu sebagai lembaga komersial, artinya tujuan dari pendirian BUMDes yaitu mencari keuntungan untuk meningkatkan Pendapatan Asli Daerah (PAD).

BUMDes Madu Sejahtera merupakan usaha desa yang bertempat di Desa Segoromadu, Kecamatan Kebomas, Kabupaten Gresik. BUMDes Madu Sejahtera berdiri sejak tahun 2017. BUMDes Madu Sejahtera dikelola langsung oleh ibu-ibu PKK. Awal mula berdirinya BUMDes yaitu karena salah satu perusahaan (PT. Latexco) yang ada di Desa Segoromadu memproduksi spring bad. Kemudian salah satu karyawan perusahaan yang berdomisili di Desa Segoromadu menawarkan kerja sama agar BUMDes Madu Sejahtera dapat memanfaatkan kesempatan tersebut yang nantinya menghasilkan beberapa produk, seperti masker, bantal, bantal leher, bantal sofa, dan guling. Selain itu, BUMDes Madu Sejahtera juga menawarkan pelayanan jasa seperti LPG, pembayaran listrik, PDAM, dan token. Namun, pada saat itu proses produksi masih manual dengan memberdayakan masyarakat Desa Segoromadu. Proses pemasaran yang dilakukan masih terbilang sangat sederhana, karena hanya dilakukan dari mulut ke mulut sehingga target pasar masih dalam lingkup Desa Segoromadu.

Masa pandemi Covid-19 mengubah berbagai sektor usaha global mulai dari perusahaan besar hingga usaha-usaha kecil mengalami permasalahan yang cukup besar. Hal tersebut juga dirasakan oleh BUMDes Madu Sejahtera. BUMDes yang sudah berdiri, namun mengalami masalah ditengah pandemi dipicu oleh beberapa faktor, salah satunya yaitu kurangnya optimalisasi strategi pemasaran yang digunakan. Faktor tersebut menjadi pemicu utama BUMDes Madu Sejahtera dalam hal pemasaran produk yang menyebabkan kurang dikenalnya produk oleh masyarakat luar Desa Segoromadu. Hal ini diperjelas melalui survey dan kegiatan wawancara dengan ibu-ibu PKK yang mengelola BUMDes Madu Sejahtera. Padahal, apabila strategi pemasaran direncanakan dengan seoptimal mungkin, tentu berpengaruh terhadap tingkat penjualan. Salah satu strategi pemasaran di masa pandemi Covid-19 adalah pemasaran secara e-commerce.

Definisi E-Commerce merupakan terobosan atau inovasi baru sebagai kegiatan transaksi jual beli barang atau layanan jasa melalui jaringan informasi salah satunya adalah internet. Menurut Adi Nugroho (2006: 1), e-commerce merupakan kegiatan jual beli serta pembayaran produk melalui media online ataupun melalui media elektronik. Dengan adanya e-commerce, tentunya memudahkan pembeli dan penjual tanpa bertemu secara langsung. Serta meluaskan hubungan komersial secara online. Hal ini sejalan dengan Kienna (2001: 4) berpendapat bahwa e-commerce merupakan membuat, mengelola, dan meluaskan hubungan komersial antara pembeli dan penjual secara online. E-Commerce dinilai sangat optimal sebagai salah satu media platform untuk strategi pemasaran, terutama BUMDes Madu Sejahtera. Media sosial menjadi kunci utama sebagai salah satu strategi pemasaran, seperti Instagram, Whatsapp, dan situs Web.

Berdasarkan uraian di atas, penulis tertarik untuk meneliti Optimalisasi Strategi Pemasaran BUMDes Melalui E-Commerce di Era Pandemi Covid-19 (Studi Kasus BUMDes Madu Sejahtera Desa Segoromadu). Karena, strategi pemasaran yang BUMDes lakukan masih secara sederhana hanya dari mulut ke mulut sehingga target pasar belum tersebar luas. Penelitian ini diharapkan mampu memberikan strategi pemasaran 
BUMDes agar produk serta layanan jasa yang ditawarkan dapat dikenal oleh masyarakat luar Desa Segoromadu guna meningkatkan nilai penjualan.

\section{Rumusan Masalah}

Berdasarkan latar belakang di atas, maka rumusan masalah yang ingin dicapai yaitu optimalisasi strategi pemasaran BUMDes Madu Sejahtera berbasis e-commerce di masa pandemi Covid-19.

\section{Tujuan}

Berdasarkan rumusan masalah di atas, maka tujuan yang ingin dicapai penulis yaitu untuk mengoptimalkan strategi pemasaran BUMDes Madu Sejahtera yang awalnya hanya dilakukan secara sederhana menjadi berbasis e-commerce agar lebih dikenal oleh masyarakat luar Desa Segoromadu di masa pandemi Covid-19 guna meningkatkan penjualan.

\section{Manfaat}

Manfaat bagi BUMDes:

- Produk dan layanan jasa semakin dikenal oleh masyarakat luar Desa Segoromadu.

- Meningkatkan nilai penjualan.

- Memperluas target pasar.

Manfaat bagi penulis:

Membantu strategi pemasaran BUMDes agar produk dan layanan jasa semakin dikenal oleh masyarakat luar Desa Segoromadu dengan membuatkan website ataupun media sosial.

\section{STUDI PUSTAKA}

\section{Badan Usaha Milik Desa (BUMDes)}

Badan Usaha Milik Desa (BUMDes) merupakan badan usaha desa yang dibentuk dan dikelola masyarakat sekitar dan pemerintahan desa dengan harapan perekonomian keuangan desa menjadi meningkat serta mensejahterakan kehidupan masyarakat berdasarkan kebutuhan dan potensi sumber daya yang ada. Tujuan BUMDes menurut Undang-Undang Nomor 32 Tahun 2004 tentang Pemerintahan Daerah, yaitu sebagai upaya atau usaha bagi desa agar Pendapatan Asli Daerah (PAD) semakin meningkat.

Landasan hukum berdirinya BUMDes yaitu UU No. 32 Tahun 2004 tentang Pemerintah Daerah, pasal 231 ayat (1) yang berbunyi "Setiap desa dapat membangun sebuah usaha berdasarkan kebutuhan dan potensi yang ada". Jadi, secara umum maksud dan tujuan dari didirikannya BUMDes yaitu sebagai salah satu bentuk usaha desa yang dikelola dan menampung seluruh kegiatan serta aspirasi masyarakat untuk berkontribusi secara langsung dalam pengelolaan kebutuhan dan potensi desa guna meningkatkan perekonomian desa.

Badan Usaha Milik Desa (BUMDes) menjadi kegiatan ekonomi sebagai lembaga sosial dan komersial. Artinya, BUMDes sebagai lembaga sosial yaitu mensejahterakan masyarakat dengan tetap memprioritaskan kepentingan masyarakat melalui kontribusinya terhadap pengelolaan langsung BUMDes baik dari segi produk maupun pelayanan jasa yang ditawarkan. Yang kedua yaitu sebagai lembaga komersial, artinya tujuan sebuah usaha tidak lain dan tidak bukan yaitu untuk mencari keuntungan yang dapat berdampak pada pendapatan asli daerah (PAD).

BUMDes diatur melalui Peraturan Daerah (Perda) karena berdirinya sebuah usaha desa dengan potensi yang ada tentunya berbeda dan beragam sesuai dengan SDA serta SDM di setiap masing-masing desa. Untuk 
itu, BUMDes didirikan berdasarkan perundang-undangan berbentuk badan hukum yang berlaku di Indonesia, serta kesepakatan antar masyarakat desa.

Berdirinya usaha desa atau BUMDes menjadikan pemerintah desa dan masyarakat sebagai pengelola BUMDes secara utuh. Pada hakikatnya, pengelola harus memiliki prinsip dasar agar BUMDes berjalan dengan sebagaimana mestinya. Prinsip-prinsip tersebut antara lain: a) kooperatif; b) transparan; c) partisipatif; d) emansipatif; e) akuntabel; f) sustainable. Prinsip-prinsip di atas harus dijalankan agar kegiatan BUMDes terus beroperasi dan dapat terus berkembang demi keberlangsungan hidup BUMDes. Artinya, pemerintahan desa beserta masyarakat memiliki peran penting dalam pendirian BUMDes, terutama dalam meningkatkan Pendapatan Asli Daerah (PADesa).

Sumber modal berdirinya BUMDes yaitu Kemendagri No. 39 Tahun 2010 dan PP No. 72 Tahun 2005, yaitu: a) anggaran dari pemerintah desa setempat yang dipisahkan; b) masyarakat, yaitu tabungan; c) bantuan dari pemerintah, baik pemerintah provinsi maupun kabupaten/kota; d) pinjaman; dan e) bagi hasil antara sektor swasta maupun masyarakat.

\section{Strategi Pemasaran}

Kotler \& Amstrong (2011) berpendapat bahwa strategi merupakan taktik yang dilakukan organisasi untuk mencapai visi dan misi dengan memperkuat keadaan ekonomi dan internal organisasi. Sedangkan pemasaran merupakan kegiatan penjualan yang dilakukan organisasi guna mencapai tujuan utama yaitu untuk memperoleh laba serta memperkuat hubungan dengan konsumen. Jadi, strategi pemasaran merupakan taktik yang dilakukan organisasi untuk mencapai tujuan utama dengan memperkuat keadaan eksternal dan internal organisasi. Hal ini sejalan dengan Sofjan Assauri, dalam buku manajemen pemasaran, berpendapat bahwa definisi strategi pemasaran merupakan rencana mendalam bagi organisasi dalam bidang pemasaran untuk mencapai visi misi perusahaan dan tujuan utama perusahaan, yaitu memperoleh laba sebanyak-banyaknya.

Dalam memaksimalkan strategi pemasaran, tentunya harus berorientasi pada upaya untuk mencapai kepuasan pelanggan dan target pasar secara luas. Konsep dan kunci utama dari strategi pemasaran adalah kepuasan konsumen atau pelanggan. Adapun langkah-langkah untuk merumuskan strategi pemasaran menurut Wibowo, et al (2015):

1. Strategi Segmentasi Pasar, merupakan kegiatan pengelompokkan pasar yang ditinjau dari karakteristik serta kebiasaan konsumen itu sendiri.

2. Strategi Penentuan Pasar Sasaran, merupakan kegiatan yang dilakukan untuk menentukan besar kecilnya segmen pasar berdasarkan kebutuhan organisasi.

3. Strategi Penentuan Posisi Pasar, merupakan sebuah strategi untuk mengambil alih konsumen melalui kepercayaan dan keyakinan konsumen itu sendiri.

\section{E-Commerce}

Semakin berkembangnya era teknologi di dunia, menuntut semua negara untuk terus mengembangkan teknologinya. Tidak hanya negara, rakyat pun juga perlu ikut andil dalam meningkatkan SDM setiap individunya. Teknologi juga tidak hanya masuk di informasi, tetapi juga masuk dalam dunia bisnis. Hal tersebut wajar bagi sebagian orang yang sebelumnya sudah mengikuti arah perkembangan teknologi dunia saat ini. Dalam dunia bisnis, selain tenaga sumber daya manusia yang diperlukan, bisnis juga terus mengupdate inovasinya melalui pemanfaatan media guna memudahkan dan menjangkau target pasar yang luas. Di masa 4.0, bisnis telah berkembang semakin pesat dengan adanya pemasaran secara online atau istilah lain yang biasa kita kenal dengan e-commerce. 
E-Commerce memiliki beragam banyak definisi. Menurut Shim et al (2000) dalam Syanto (2003) menjelaskan bahwa definisi e-commerce merupakan inovasi terbaru dalam kegiatan jual beli antara pembeli dan penjual tanpa bertatap muka secara langsung atau proses kegiatan menjual dan membeli yang dilakukan secara online melalui jaringan internet, seperti World Wide Web ataupun media sosial lainnya. Sedangkan menurut Turban dkk (2008), e-commerce merupakan proses transaksi bagi penjual dan pembeli yang dilakukan secara online melalui jaringan internet. Berdasarkan definisi tersebut, e-commerce merupakan inovasi terbaru dalam kegiatan transaksi jual beli antara pembeli dan pedagang tanpa bertatap muka secara langsung, serta dapat dilakukan di seluruh dunia.

Kalakota dan Whinston (1997) mendefinisikan e-commerce dalam berbagai sudut pandang, yaitu:

1. Sudut pandang komunikasi. Definisi e-commerce dari sudut pandang ini yaitu sebagai alat pengiriman sebuah informasi yang berisi mengenai katalog produk atau layanan serta sarana elektronik.

2. Sudut pandang proses bisnis. Definisi e-commerce merupakan sebagai media teknologi menuju otomisasi transaksi dan aliran kinerja perusahaan atau organisasi.

3. Sudut pandang online. Definisi e-commerce berkaitan dengan kapasitas atau daya tampung jual beli produk dan informasi di internet serta jasa online lainnya.

4. Sudut pandang layanan. Definisi e-commerce merupakan alat penting yang dibutuhkan sebagai pemenuhan kebutuhan organisasi, konsumen, serta manajemen.

E-Commerce sebagai salah satu alat penting bagi sebuah bisnis atau organisasi, salah satunya adalah usaha desa atau BUMDes. Penggunaan e-commerce sangat dibutuhkan dalam dunia bisnis sebagai salah satu jembatan agar dapat bersaing dengan bisnis lain dalam skala global. Menurut Yau (2002), e-commerce mampu memberikan dampak positif bagi dunia bisnis, yaitu (a) mampu meningkatkan efisiensi; (b) meminimalisir dana; (c) barang atau produk menjadi lebih terkontrol; (d) kegiatan distribusi menjadi teratur; (e) mempertahankan citra perusahaan atau organisasi terhadap kepuasan pembeli serta menjaga kualitas atau kuantitas agar bisnis tetap berjalan dengan baik dengan penjual (supplier).

Seorang penjual wajib untuk mempunyai kemampuan yang teliti tentang kebiasaan atau tindakan konsumen agar mampu menciptakan pasar yang baik sesuai dengan arus perubahan yang konsisten dan berkelanjutan demi keberlangsungan suatu usaha organisasi. Selain itu penjual juga harus mengamati berbagai perilaku atau tindakan konsumen. Tindakan konsumen mampu memberikan gambaran tentang cara-cara bagaimana konsumen membuat keputusan terhadap pembelian, bagaimana penggunaan pembelian tersebut, serta bagaimana mereka mengatur atau menyusun pembelian barang atau jasa sehingga kebutuhan mereka terpenuhi sesuai apa yang dibutuhkan dan diperlukan di dalam kebutuhannya (Wandanaya, 2012).

\section{METODE PENELITIAN}

Metode penelitian yang dilakukan penulis menggunakan penelitian deskriptif kualitatif. Metode kualitatif yang digunakan sesuai dengan permasalahan yang sedang diteliti yakni Optimalisasi Strategi Pemasaran BUMDes melalui E-Commerce di Era Pandemi Covid-19 (Studi Kasus BUMDes Madu Sejahtera Desa Segoromadu). Penelitian ini dijabarkan dalam bentuk deskriptif yang membahas tentang bagaimana strategi pemasaran yang dilakukan BUMDes melalui e-commerce dalam memasarkan produknya secara onlone. Sedangkan jenis pendekatan yang digunakan adalah pendekatan yang bertujuan untuk mendalami secara detail bagaimana interaksi sosial, individu, organisasai dan lain-lain terkait dengan permasalah yang terjadi di tempat (Primasatya, 2014) 
Lokasi penelitian dilakukan di BUMDes Madu Sejatera Desa Segoromadu yang bertempat di Jl. Segoromadu 1 No.40, Segoromadu Gending, Kec. Kebomas, Kabupaten Gresik, Jawa Timur 61123 pada bulan Mei sampai dengan bulan Juli. Teknik pengumpulan data yang digunakan meliputi kegiatan:

1. Observasi partisipatif pasif, penelitian melakukan observasi dengan mendatangi kantor BUMDes Madu Sejahtera untuk melihat keadaan BUMDes dan hanya mengamati segala aktivitas BUMDes.

2. Wawancara, menggunakan teknik wawancara terstruktur untuk mendapatkan informasi mendalam dari informan.

3. Dokumentasi, data penelitian diperoleh dari wawancara langsung dan via chat..

\section{HASIL DAN PEMBAHASAN}

Kuliah Kerja Nyata Tematik "Bangkit Dimasa Pandemi” ini sebagai bentuk implementasi dari kegiatan Tridarma Perguruan Tinggi Negeri. Kegiatan ini sebagai wujud peran aktif mahasiswa untuk mengatasi problem, membangun dan mengembangkan desa Segoromadu. Kegiatan ini bersinergi dengan berbagai pihak yaitu Lembaga Penelitian dan Pengabdian kepada Masyarakat (LPPM) UTM, BUMDes desa, pemerintah desa, dan masyarakat Desa Segoromadu. Adanya kegiatan optimalisasi strategi pemasaran BUMDes melalui E-Commerce di Era Pandemi Covid 19 di desa Segoromadu diharapkan dapat berperan penting dalam usaha warga desa untuk bangkit di masa pandemi.

BUMDes Madu Sejahtera merupakan usaha milik desa berbentuk badan yang bertempat di Desa Segoromadu, Kecamatan Kebomas, Kabupaten Gresik. BUMDes Madu Sejahtera berdiri sejak tahun 2017. BUMDes Madu Sejahtera dikelola langsung oleh ibu-ibu PKK yang menghasilkan beberapa produk, seperti masker, bantal, bantal leher, bantal sofa, dan guling. Selain itu, BUMDes Madu Sejahtera juga menawarkan pelayanan jasa seperti LPG, pembayaran listrik, PDAM, dan token.

Di masa pandemi Covid-19, berbagai sektor usaha global dari perusahaan besar hingga usaha-usaha kecil mengalami permasalahan yang cukup besar. Hal tersebut juga dirasakan oleh BUMDes Madu Sejahtera. BUMDes yang sudah berdiri, namun mengalami masalah ditengah pandemi dipicu oleh beberapa faktor, salah satunya yaitu kurangnya optimalisasi strategi pemasaran yang digunakan. Proses pemasaran yang dilakukan masih terbilang sangat sederhana, karena hanya dilakukan dari mulut ke mulut sehingga target pasar masih dalam lingkup Desa Segoromadu. Faktor tersebut menjadi pemicu utama BUMDes Madu Sejahtera dalam hal pemasaran produk yang menyebabkan kurang dikenalnya produk oleh masyarakat luar Desa Segoromadu. Informasi tersebut diperkuat melalui wawancara anatara peneliti dengan ibu-ibu PKK yang mengelola BUMDes Madu Sejahtera. Padahal, apabila strategi pemasaran direncanakan dengan seoptimal mungkin, tentu berpengaruh terhadap tingkat penjualan. Salah satu strategi pemasaran di masa pandemi Covid-19 adalah pemasaran secara e-commerce.

Web Desa merupakan salah satu bentuk inovasi yang sedang dioptimalkan oleh BUMDes Madu Sejahtera dengan melakukan pemasaran produk BUMDes berbasis online melalui aplikasi market place yang diciptakan oleh KKNT 28 atas rekomendasi serta permintaan Kepala Desa Segoromadu untuk memperluas pemasaran produk, tidak hanya lingkup warga desa segoromadu tetapi juga desa lain, bahkan di kecamatan dan kabupaten di sekitar. Salah satu bentuk kegiatannya yaitu dengan memberikan inovasi serta menciptakan web desa untuk tujuan optimalisasi strategi pemasaran produk-produk BUMDes.

Selama pelaksanaan kegiatan ini pandemi Covid-19 masih berlangsung, sehingga pembuatan Web Desa dilakukan secara mandiri oleh Mahasiswa KKNT 28. Disamping itu dilakukan pengumpulan sumber data dan produk yang nantinya dikelola beriringan dengan pembuatan E-Commerce itu sendiri. Produk yang 
dikumpulkan kemudian diolah dan dikembangkan lagi dengan cara pemotretan produk-produk dari BUMDes antara lain masker dan bantal guling yang nantinya diupload melalui situs Web Desa E-Commerce dan dipasarkan melalui Market Place. Pemotretan ini dimaksudkan agar meningkatkan minat pembeli dengan gambar dan tampilan yang lebih menarik. Foto produk sebelum dan sesudah dilakukan pemotretan ditunjukkan pada gambar 1, 2, dan 3.

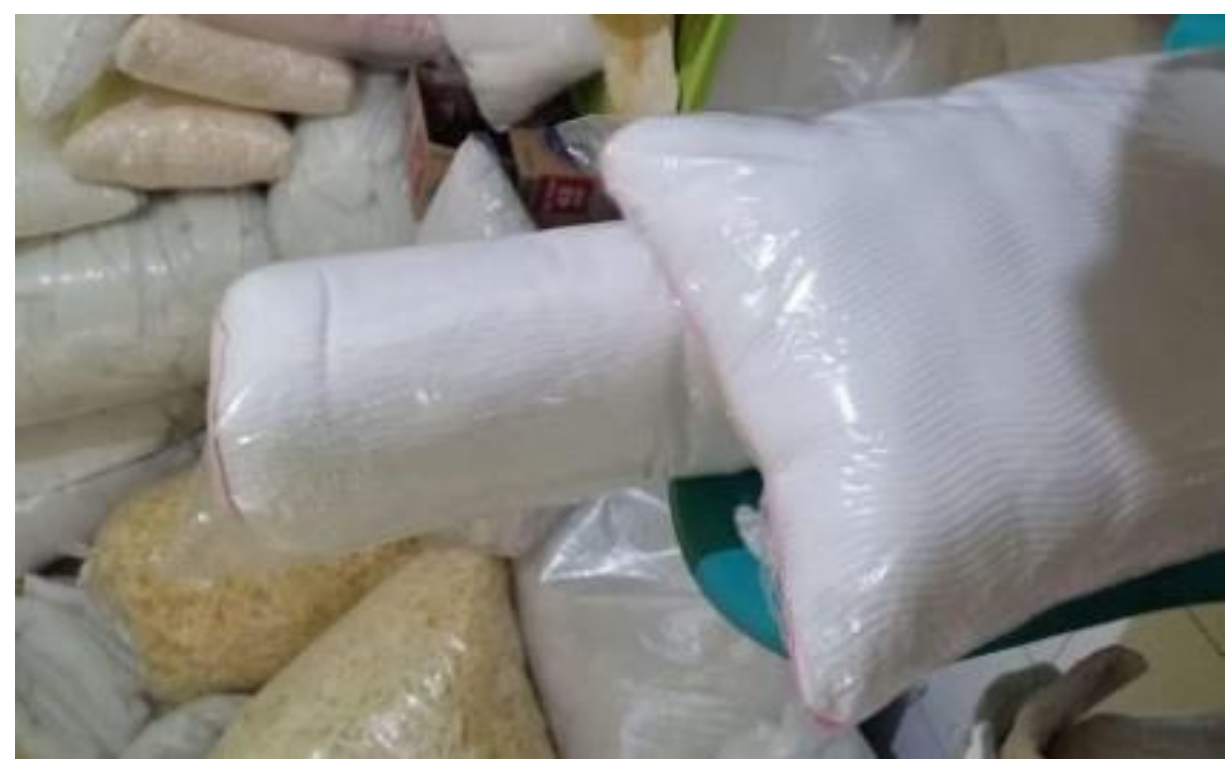

Gambar 1. Produk BUMDes sebelum dilakukan foto produk

Sumber: Hasil Olah Penulis, 2021

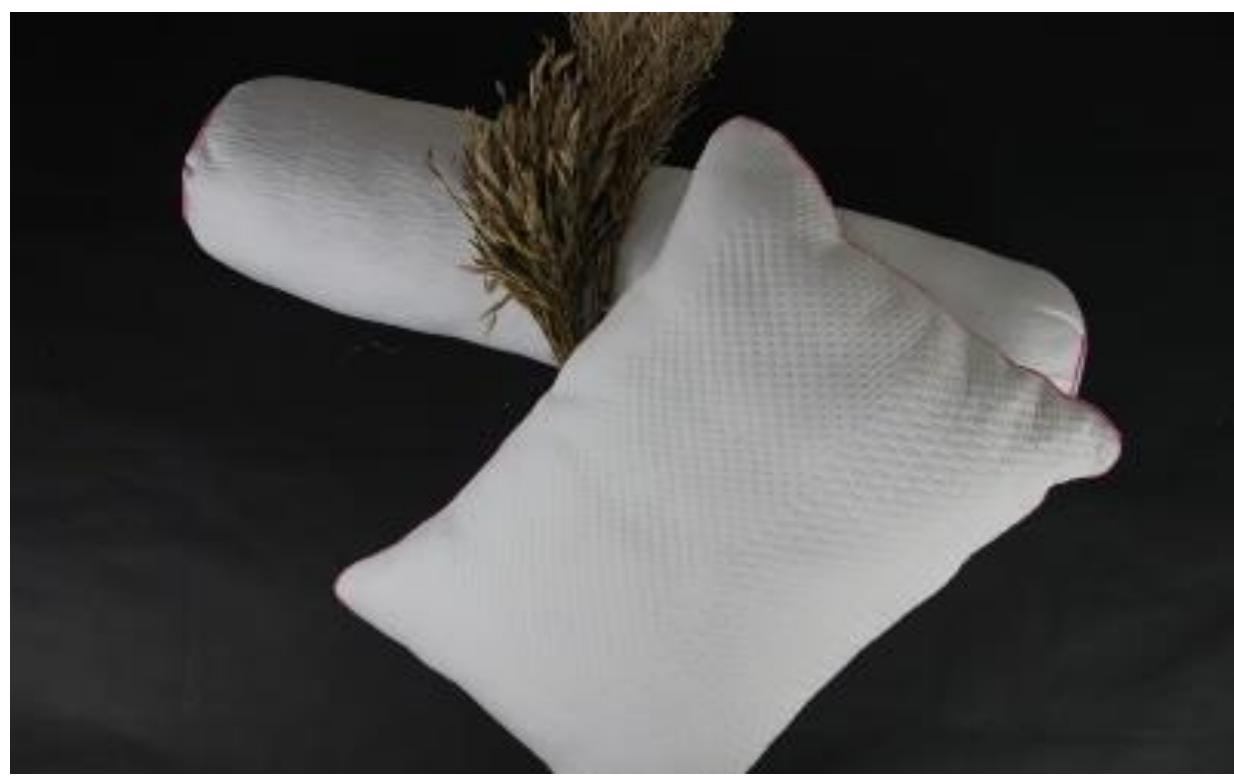

Gambar 2. Foto produk bantal dan guling

Sumber: Hasil Olah Penulis, 2021 


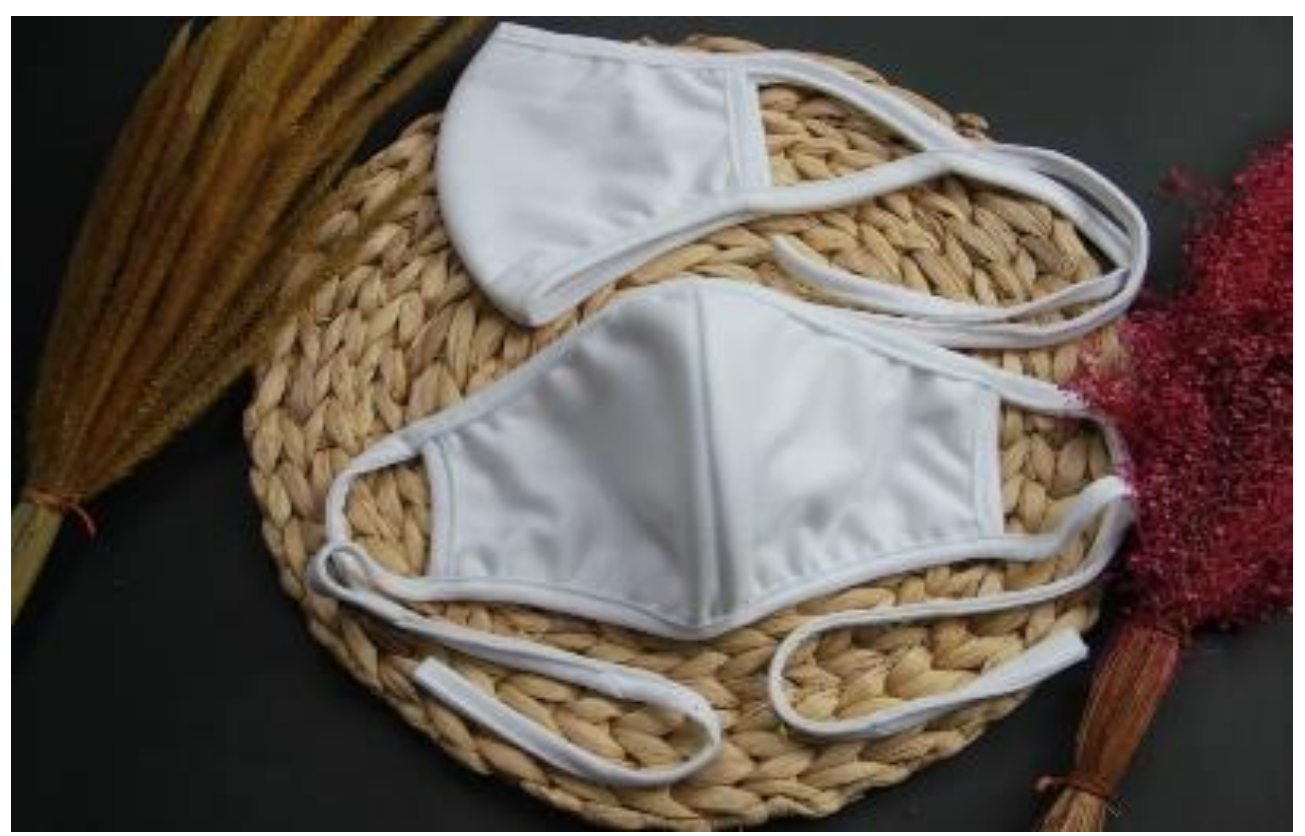

Gambar 3. Foto produk masker kain

Sumber: Hasil Olah Penulis, 2021

Pembuatan Web Desa dilakukan melalui beberapa tahapan kegiatan diantaranya :

a. Uraian kegiatan

i. Analisis Kebutuhan

Dalam tahap ini, developer menganilisis kebutuhan dari system yang akan dibuat, seperti: fitur-fitur, layanan, dan lain-lain

ii. Desain Perancangan

Mendesain rancangan antarmuka web (front-end), use case diagram, dan rancangan system yang akan dibuat.

iii. Pemrograman

Merupakan tahap inti pembuatan website, berdasarkan kebutuhan yang sudah di analisa, web dikembangan dengan system front-end menggunakan HTML, CSS, dan JavaScript. Mengedepankan grafis antarmuka, sehingga pengguna dapat melihat dan berinteraksi dengan data itu. System ini nantinya akan menampilkan katalog dan layanan dari bumdes tersebut. Untuk masalah transaksi, melibatkan aplikasi whatsapp. Dimana whatsapp menjadi kegemaran masyarakat saat ini, dan mempermudah masalah antar penjual dan pembeli. Setelah program dibuat akan di online kan menggunakan github pages yang dicustom untuk domainnya, seperti tampak pada gambar 4.

iv. Pengujian

Dilakukan pengujian untuk mengecek sistem yang telah dirancang apakah sudah sesuai yang dibutuhkan atau belum dengan pengujian black box (pengujian sistem atau aplikasi perangkat lunak yang sedang dikembangkan).

b. Target Kegiatan

Pengembangan sudah dilakukan, dan website sudah dapat diakses. Beralamat di https://segoromadu.store/ seperti tampak pada gambar 5 s.d 8 . 


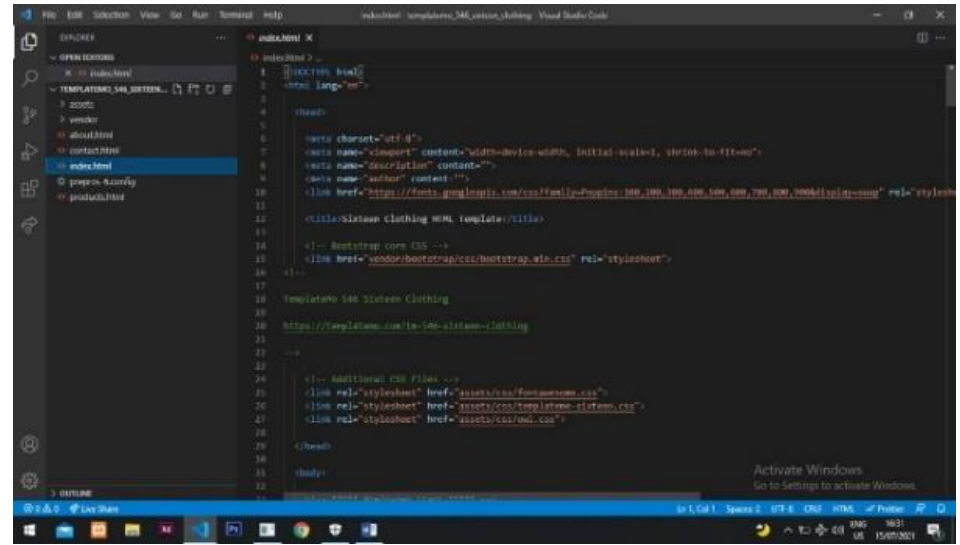

Gambar 4 Desain rancangan Web Desa menggunakan aplikasi Visual Studio Code Sumber: Hasil Olah Penulis, 2021

Foto dari produk-produk BUMDes kemudian di input pada situs Web Desa yang telah dibuat sebelumnya. Dari Web desa ini kemudian disebarluaskan ke berbagai media masa guna memperluas pemasaran produk Bumdes. Media massa yang menjadi target utama yaitu Whatsapp, Marketplace Facebook, Instagram, serta media massa lainnya yang memiliki potensi untuk mengoptimalkan pemasaran produk.

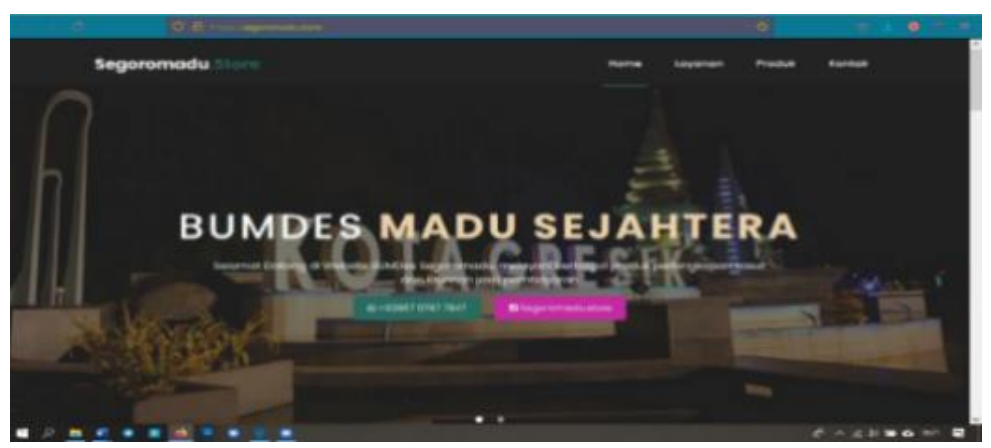

Gambar 5. Tampilan Menu Utama Web Desa Segoromadu

Sumber: Hasil Olah Penulis, 2021

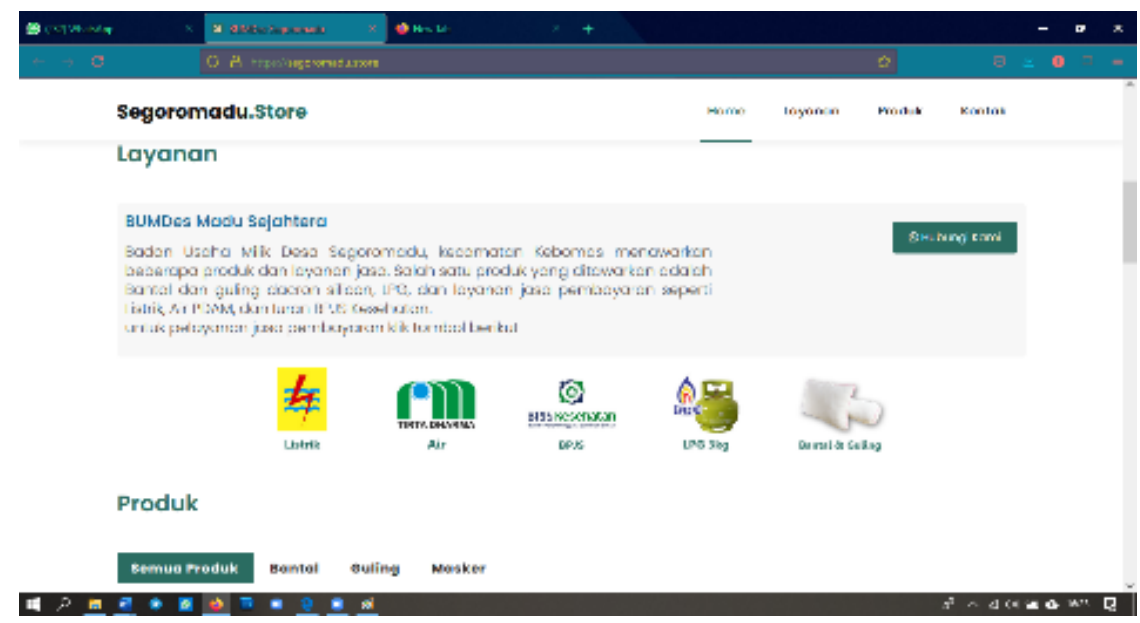

Gambar 6. Katalog pelayanan jasa BUMDes Madu Sejahtera

Sumber: Hasil Olah Penulis, 2021 


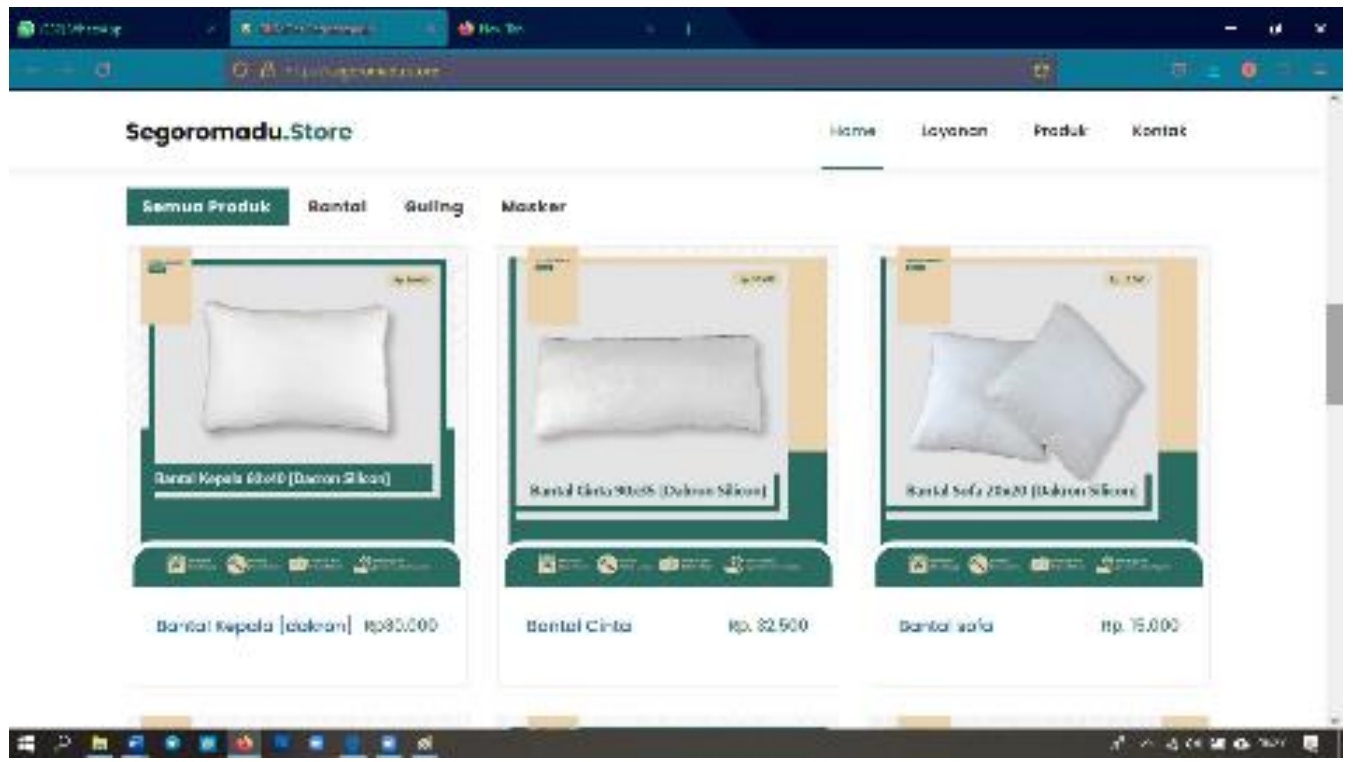

Gambar 7. Katalog produk-produk BUMDes Madu Sejahtera

Sumber: Hasil Olah Penulis, 2021

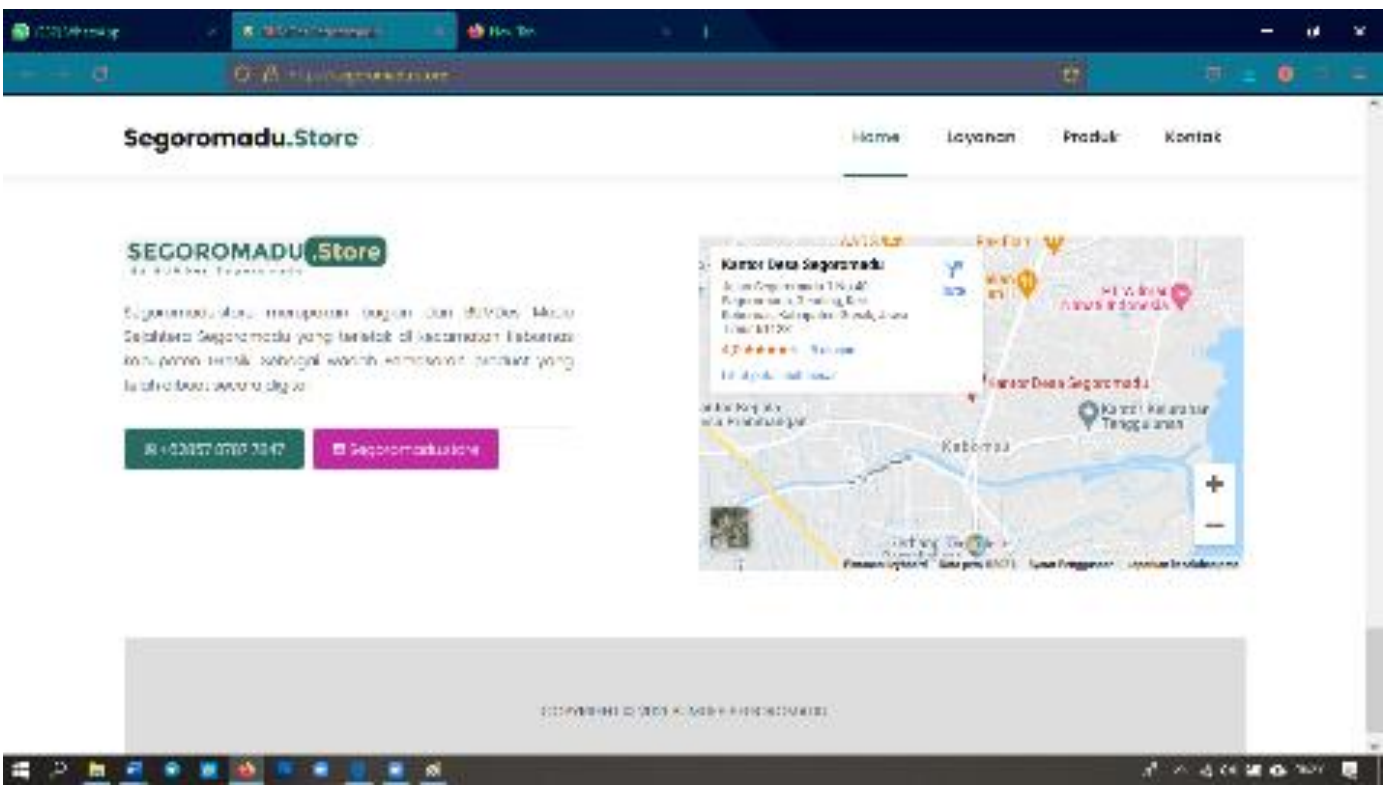

Gambar 8. Informasi umum BUMDes Madu Sejahtera

Sumber: Hasil Olah Penulis, 2021

Pemasaran online melalui web (teknologi digital) saat ini sudah banyak digunakan dalam seluruh aspek kehidupan manusia, sehingga pada pelaku usaha (termasuk BUMDes) harus bisa beradaptasi dengan kemajuan teknologi yang ada agar dapat terus berjalan dan berkembang. Digital marketing ini merupakan cara berinteraksi antara pembeli dan penjual tanpa batas waktu dan geografis (Purwana et al., 2017; Selander et al., 2013; Syamsiah, 2018). Kegiatan jual beli melalui online harus memperhatikan kejelasan informasi dari produk yang diperjual belikan, selain itu kemasan (packaging) produk juga sangat penting. Hal ini akan mempengaruhi keberhasilan usaha dalam digital marketing (Christine, 2000; Irrubai, 2015; Pradiani, 2018). Selain melalui web pemasaran, dapat juga memanfaatkan media sosial dalam pemasaran produk UKM (Nuryskha et al., 2015; Puspitasari et al., 2019). Strategi pemasaran online berpengaruh signifikan terhadap minat beli konsumen (Akhmad, 2015; Jati \& Yuliansyah, 2017; Khazim, 2016; Sarastuti, 2017). Salah satu yang perlu diperhatikan dalam pemasaran online adalah benchmarking, yaitu bagian dari manajemen untuk 
menganalisa seberapa besar produk memberikan kepuasan kepada konsumen (Fadly \& Sutama, 2020; Putri, 2016b). Hal ini juga didukung dan diperkuat oleh penelitian yang sudah ada sebelumnya terkait dengan strategi pemasaran online dan benchmarking (Syahputra, 2017; Thousani et al., 2015; Wahana et al., 2014). Dalam sosialisasi pemasaran online, juga disampaikan terkait dengan benchmarking. Benchmarking merupakan bagian dari proses menemukan style baru yang lebih baik dalam melakukan sesuatu, dalam hal ini adalah produk. Terbukti dari penelitian sebelumnya bahwa desain strategi pemasaran online signifikan melalui evaluasi benchmarking (Putri, 2016) Beberapa tahapan yang perlu dilakukan dalam proses benchmarking, antara lain plan, search, observe, analyze, dan adapt (Paulus \& Devie, 2013).

Pengukuran tingkat keberhasilan kegiatan yang dilakukan pada sasaran yaitu dengan melihat perkembangan dari penjualan produk BUMdes. Dari penjualan E-Commerce awal terdapat pemesanan secara online bantal kepala 5 pcs, guling polos 2 pcs, dan guling motif 2 pcs. Hasil penjualan yang ada menunjukkan terjadinya peningkatan pembelian setelah dilakukan optimalisasi strategi pemasaran produk BUMDes. Manfaat dari optimalisasi strategi pemasaran melalui E-Commerce tak hanya peningkatan dari segi penjualan, tetapi juga memperluas area pemasaran dengan didukung adanya penjualan secara E-Commerce, dan hal ini dapat berjalan secara berkelanjutan. Karena masyarakat dapat mengakses/memperoleh informasi setiap saat dengan bebas tentang kebutuhan yang mereka butuhkan, yaitu mengakses Web Desa, maupun sosial media yang sebelumnya telah disebarluaskan. Hal ini juga dapat menghemat biaya dan waktu. Adanya kegiatan pengabdian pada masyarakat berupa optimalisasi strategi pemasaran BUMDes melalui E-Commerce di Era Pandemi ini diharapkan dapat meningkatkan penjualan BUMDEs Madu Sejahtera secara berkelanjutan. Salah satunya dengan meningkatkan penjualan secara E-Commerce karena dapat meningkatkan perekonomian BUMDes.

\section{KESIMPULAN}

Dengan adanya kegiatan pengabdian yang dilakukan terbukti berhasil meningkatkan penjualan pemasaran BUMDes Madu Sejahtera desa Segoromadu. Kegiatan ini memanfaatkan E-Commerce atau pemasaran secara online melalui web (teknologi digital) yang dapat diakses oleh seluruh aspek kehidupan manusia, sehingga pada pelaku usaha (termasuk BUMDes) harus bisa beradaptasi dengan kemajuan teknologi yang ada agar dapat terus berjalan dan berkembang. Digital marketing ini merupakan cara berinteraksi antara pembeli dan penjual tanpa batas waktu dan geografis (Purwana et al., 2017; Selander et al., 2013; Syamsiah, 2018). Optimalisasi strategi penjualan BUMDes dapat dilihat dari perkembangan/peningkatan penjualan produk BUMdes. Hasil penjualan yang ada menunjukkan terjadinya peningkatan pembelian setelah dilakukan optimalisasi strategi pemasaran produk BUMDes. Manfaat dari optimalisasi strategi pemasaran melalui ECommerce tak hanya peningkatan dari segi penjualan, tetapi juga memperluas area pemasaran dengan didukung adanya penjualan secara E-Commerce, dan hal ini dapat berjalan secara berkelanjutan serta menghemat biaya dan waktu. Diharapkan kegiatan pengabdian yang dilakukan KKNT 28 UTM dapat berjalan secara berkelanjutan oleh ibu-ibu PKK BUMDes karena dapat meningkatkan dari segi penjualan dan juga perekonomian BUMDes. Namun, keterbatasan dalam penelitian ini yaitu tidak semua dokumentasi mengenai BUMDes Madu Sejahtera, seperti laporan keuangan setiap bulan tidak diperbolehkan untuk dipublish, hanya diperbolehkan untuk sekedar melihat, karena laporan keuangannya masih berbentuk manual atau tulis tangan. Untuk penelitian selanjutnya, diharapkan agar dapat mencari solusi agar laporan keuangan tersebut diupdate lebih modern lagi. 


\section{DAFTAR PUSTAKA}

Adam, H., Ristawati, R., Ramadhanti, S., \& Nugraha, X. (2020). Pembentukan Badan Usaha Milik Desa Di Sumberanyar Pasuruan Untuk Peningkatan Kesejahteraan Masyarakat. Jurnal Pengabdian Kepada Masyarakat, 293-299.

Febryani, H., Nurmalia, R., Lesmana, I. M., \& Dkk. (2018). Keberadaan Badan Usaha Milik Desa (Bumdes) Sebagai Penguatan Ekonomi Desa Abiantuwung. Jurnal Ilmiah Akuntansi Dan Humanika, 95-103.

Kotler, Philips \& Armstrong, Gary. 2011. Prinsip-Prinsip Pemasaran. Erlangga: Jakarta.

Noviandari, I., Kusumo, B., \& Syafi'i. (2021). Sosialisasi Strategi Pemasaran Produk Secara Online Offline Kepada Masyarakat Desa Seketi, Balongbendo, Sidoarjo. Jurnal Pengabdian Lppm Untag Surabaya, 5-9.

Pradnyani, N. L. (2019). Peranan Badan Usaha Milik Desa (Bumdes) Dalam Meningkatkan Kesejahteraan Masyarakat Di Desa Tibubeneng Kuta Utara. Jurnal Riset Akuntansi, 39-47.

Pratiwi, M. B., \& Novianty, I. (2020). Strategi Bertahan Badan Usaha Milik Desa (Bumdes) Dalam Pandemi Covid-19 Pada Desa Cibodas Kecamatan Lembang Kabupaten Bandung Barat. 1098-1104.

Ramadana, C. B., Ribawanto, H., \& Suwondo. (N.D.). Keberadaan Badan Usaha Milik Desa (Bumdes) Sebagai Penguatan Desa (Studi Di Desa Landungsari, Kecamatan Dau, Kabupaten Malang). Jurnal Administrasi Publik, 10681076.

Sasauw, C., Gosal, R., \& Waworundeng, W. (2018). Efektivitas Badan Usaha Milik Desa (Bumdes) Dalam Meningkatkan Masyarakat Di Desa Lenganeng Kecamatan Tabukan Utara Kabupaten Kepulauan Sangihe. Jurnal Jurusan Ilmu Pemerintahan, 1-10.

Suhu, B. L., Djae, R. M., \& Sosoda, A. (2020). Analisis Pengelolaan Badan Usaha Milik Desa (Bumdes) Di Desa Geti Baru Kecamatan Bacan Barat Utara Kabupaten Halmahera Selatan. Jurnal Government Of Archipelago, 1-7.

Suwarni, L., Sarwono, E., Suryadi, E., \& Selviana. (2020). Sosialisasi Strategi Dan Web Pemasaran Online (Ppdm Di Desa Rasau Jaya Satu). International Journal Of Community Service Learning, 274-281.

Umar, Husein. 2001. Strategic Management in Action. PT Gramedia Pustaka Utama: Jakarta.

Utami, K. S., Tripalupi, L. E., \& Meitriana, M. A. (2019). Peran Badan Usaha Milik Desa (Bumdes) Dalam Peningkatan Kesejahteraan Anggota Ditinjau Melalui Kewirausahaan Sosial. Jurnal Pendidikan Ekonomi, 498-508.

Widayanti, R. E., \& Oktafia, R. (2021). Strategi Pemasaran Berbasis Online Pada Produk Badan Usaha Milik Desa (Bumdes) "Sukses Bersama" Desa Sugihwaras Kabupaten Sidoarjo. Jurnal Tabarru', 242-252.

Zunaidah, A., Askafi, E., \& Daroini, A. (2020). Strategi Pengembangan Badan Usaha Milik Desa (BUMDES). Otonomi, $241-247$. 